\title{
A capabilities approach to remedies for systemic resource-related socio- economic rights violations in South Africa
}

\author{
Shanelle van der Berg* \\ Research Fellow, Department of Public Law, University of Stellenbosch, South \\ Africa \\ https://orcid.org/0000-0001-6935-8818
}

\section{Summary}

The judiciary plays a key role in holding the government accountable for its socio-economic policies. By adhering to certain tenets that underlie both South Africa's transformative Constitution and Sen and Nussbaum's capabilities approach, courts can promote the foundational values of dignity, equality and freedom, broaden participation and ensure accountability. Since government's priorities are most clearly reflected in its budgetary allocations, courts should apply a capabilities-based standard of proportionality review where it is claimed that a socioeconomic right has been violated due to disproportionate resource allocation. In this article, the focus shifts to the implications of adopting a capabilities approach at the remedial phase of adjudication. Given that the South African Constitution demands 'effective' relief where a constitutional right has been infringed, it is argued that efficacy can be assessed by a remedy's ability to realise the capabilities that form the content of the infringed socio-economic right. Furthermore, where socioeconomic rights are infringed upon on a systemic level through unreasonable resource allocation, key principles that inform a capabilities

BA LLB LLD (Stellenbosch); shanellevdb@gmail.com. The financial assistance of the National Research Foundation (NRF) towards this research study is hereby acknowledged. Opinions expressed and conclusions arrived at, are those of the author and are not necessarily to be attributed to the NRF. This article was written in the author's erstwhile capacity as Mellon Early Research Career Fellow, Socioeconomic Rights and Administrative Justice Research Project (SERAJ), Faculty of Law, Stellenbosch University, South Africa. Thanks are due to the insightful comments provided by two anonymous referees. Any remaining errors are my own. 
approach to adjudication can be incorporated into the design of structural interdicts to ensure lasting capability realisation and institutional reform. Where all these principles are observed, effective relief can ensue. Finally, the incorporation of these principles into remedial design can help mitigate separation of powers-based concerns that the judiciary lacks the institutional competence and legitimacy required to adjudicate complex, polycentric matters of government resource allocation.

Key words: socio-economic rights; South African Constitution; effective remedies; capabilities approach

\section{Introduction}

Justiciable socio-economic rights mean little without domestic legal systems that afford access to effective remedies for rights violations. ${ }^{1}$ While most international and regional human rights instruments oblige state parties to fulfil human rights and provide remedies where violations are alleged, ${ }^{2}$ many national jurisdictions lack a principled basis on which to formulate effective relief. Drawing from the South African Constitutional Court and other jurisprudence, this article proposes a paradigm for use by the judiciary to craft effective remedies while not encroaching upon the separation of powers doctrine. The conceptual framework draws from tenets common to both South Africa's transformative Constitution and Sen and

1 South Africa recently faced a crisis in its social security administration which exposed millions of vulnerable grant beneficiaries to the complete denial of their right to social assistance, as guaranteed by sec 27 of the Constitution of the Republic of South Africa, 1996. The predicament arose after a 2014 judgment of the Constitutional Court that the South African Social Security Agency (SASSA) had run an unlawful tender process for the administration of social grants by a third party provider; Allpay Consolidated Investment Holdings (Pty) Ltd $v$ Chief Executive Officer of the South African Social Security Agency 2014 (1) SA 604 (CC) (Allpay I). In order not to jeopardise the vital interest that grant beneficiaries have in uninterrupted grant payment, the resultant declaration of invalidity was suspended until a new tender process was run, or SASSA took over the administration of grants at the expiration of the invalid contract on 31 March 2017; Allpay Consolidated Investment Holdings (Pty) Ltd v Chief Executive Officer of the South African Social Security Agency (No 2) 2014 (4) SA 179 (CC) (Allpay II). However, the Constitutional Court subsequently on several occasions had to intervene to further extend the operation of the contract due to non-performance and false assurances provided by SASSA. Black Sash Trust $v$ Minister of Social Development (Freedom Under Law NPC Intervening) 2017 (3) SA 335 (CC) (Black Sash I); South African Social Security Agency $v$ Minister of Social Development 2018 10 BCLR 1291 (CC) (SASSA); Black Sash Trust $v$ Minister of Social Development (Freedom Under Law Intervening) 201812 BCLR 1472 (CC) (Black Sash II).

2 In the African regional context, see art 7(1)(a) of the African Charter on Human and Peoples' Rights. See further M Ssenyonjo 'Analysing the economic, social and cultural rights jurisprudence of the African Commission: 30 Years since the adoption of the African Charter' (2011) 29 Netherlands Quarterly of Human Rights 358371. 
Nussbaum's capabilities approach. ${ }^{3}$ The Constitution seeks to '[i]mprove the quality of life of all citizens and free the potential of each person', 4 whereas the capabilities approach congruently asks to what extent people have the potential (or substantive freedom) to choose the lives they have reason to value..$^{5}$ This framework may be adapted for use by African jurisdictions that entrench justiciable socioeconomic rights, ${ }^{6}$ and may further aid other jurisdictions that do not yet provide for effective remedies where socio-economic rights are infringed. ${ }^{7}$ Whereas judicial intervention is ultimately no panacea in the face of systemic government intransigence, a sound theoretical grounding nevertheless makes effective relief possible.

The article builds on previous research studies that sought to demonstrate that the adoption of a capabilities approach to adjudication practically can assist and theoretically justify the South African judiciary's review of government resource allocation decisions that impact socio-economic rights. ${ }^{8}$ Since government's priorities are most clearly reflected in its budgetary allocations, courts should apply a capabilities-based standard of proportionality review where it is claimed that a socio-economic right has been violated due to disproportionate resource allocation. In the article the focus shifts to the implications of adopting a capabilities approach at the remedial phase of adjudication of government resource allocation decisions that impact socio-economic rights. Given that the Constitution demands 'effective' relief where a constitutional right has been infringed, it is argued that efficacy can be assessed by a remedy's ability to realise the capabilities that form the content of the infringed socio-economic right. Where socio-economic rights are infringed upon on a systemic level through unreasonable resource allocation, key principles that inform a capabilities approach to adjudication can be incorporated into the design of structural interdicts to ensure lasting capability realisation and institutional reform.

3 A Sen Development as freedom (1999); A Sen The idea of justice (2009); MC Nussbaum Women and human development: The capabilities approach (2000); MC Nussbaum Creating capabilities (2011).

4 Preamble to the South African Constitution.

5 Sen (1999) (n 3) 74.

6 Eg, the Constitution of Ghana (1992) and the Constitution of Kenya (2010).

7 See eg the case of Cameroon, as expanded in AA Agbor 'Pursuing the right to an effective remedy for human rights violation in Cameroon: The need for legislative reform' (2017) 20 Potchefstroom Electronic Law Journal 27.

8 See generally S van der Berg 'A capabilities approach to the judicial review of resource allocation decisions impacting on socio-economic rights' unpublished LLD thesis, University of Stellenbosch, 2015; S van der Berg 'The need for a capabilities-based standard of review for the adjudication of state resource allocation decisions' (2015) 31 South African Journal on Human Rights 330; $S$ van der Berg 'Ensuring proportionate state resource allocation in socio-economic rights cases' (2017) 134 South African Law Journal 576.

9 For the need to apply a capabilities-based standard of review, see Van der Berg (2015) (n 8). 
First, courts should direct a process of participation and informational broadening to ensure that the capability needs underlying the violated socio-economic rights are comprehensively determined. Next, courts must provide explicit normative guidelines to guide government and all stakeholders in their engagement efforts with a view to formulating improved allocative plans. Simultaneously, courts should require government to present explicit evidence of the processes followed to arrive at a proportionate remedial plan. Finally, the revisability of judgments should be catered for by retaining judicial supervision. Where all these principles are observed, effective relief can ensue. Moreover, the incorporation of these principles into remedial design can help mitigate separation of powers-based concerns that the judiciary lacks the institutional competence and legitimacy required to adjudicate complex, polycentric matters of government resource allocation.

The article commences with an exposition of the South African judiciary's remedial powers by highlighting key jurisprudential examples that illustrate the range of remedies at courts' disposal. It is subsequently argued that the judiciary should overcome its ostensible reluctance to retain supervision following findings of socio-economic violations, and suggests that participatory structural interdicts may strike an appropriate balance between the need for effective relief and maintenance of the separation of powers between different branches of government. Finally, a capabilities approach to remedies is espoused.

\section{South African judiciary's remedial powers}

\subsection{A capabilities approach to remedies in the context of South Africa's project of transformative constitutionalism}

South Africa remains one of the most unequal countries in the world, and over half of its population continues to live in poverty. ${ }^{10}$ It is within this context that South Africa's Constitution should be viewed. South Africa's project of 'transformative constitutionalism' envisions a process of 'constitutional enactment, interpretation, and enforcement committed ... to transforming a country's political and social institutions and power relationships in a democratic, participatory, and egalitarian direction' ${ }^{11}$ In order to achieve a substantively equal society, the realisation of the various socio-economic rights enshrined in the Constitution is essential. ${ }^{12}$ This, in turn, requires significant resources to be expended by government in order to redress the

10 Stats SA Poverty trends in South Africa: An examination of absolute poverty between 2006 and 2015 (2017) 17.

11 KE Klare 'Legal culture and transformative constitutionalism' (1998) 14 South African Journal on Human Rights 146150.

12 Eg secs 26, 27, $28 \& 29$ of the Constitution. 
systemic and infrastructural imbalances inherited from South Africa's apartheid past. Constitutional transformation furthermore requires a shift from a 'culture of authority' to a 'culture of justification', in terms of which the exercise of public power must be justified with reference to value-based reasons. ${ }^{13}$

The capabilities approach of Sen and Nussbaum, which centres on the question as to whether people possess the substantive freedom or 'capabilities' to choose meaningful lives, resonates strongly with South Africa's constitutional project, in general, and the inclusion of justiciable socio-economic rights, in particular. It has been demonstrated elsewhere that the capabilities approach can assist courts in imbuing socio-economic rights with context-dependent content, thereby aiding the judiciary in subjecting impugned government allocative decisions to proportionality review. ${ }^{14}$ Moreover, it has been shown that certain tenets central to both South Africa's project of transformative constitutionalism and the capabilities approach can be distilled and applied throughout the adjudicatory process. ${ }^{15}$ Where courts are tasked with formulating effective remedies for systemic, disproportionate government resource allocation that results in the infringement of socio-economic rights, three of these principles become particularly relevant: First, participation is crucial to a project of transformative constitutionalism, ${ }^{16}$ and finds its corollary in Sen's emphasis on public reasoning and informational broadening. ${ }^{17}$ Next, substantive reasoning on the part of all public actors, including the judiciary, is integral to a culture of justification, ${ }^{18}$ and is congruent with the requirement for explicitness in the making of evaluative judgments in terms of the capabilities approach. ${ }^{19}$ Finally, these tenets must be combined with judicial supervision in order to ensure effective remedies. Supervision enables revisable judgments, for which the need is recognised by Sen. 20

The capabilities approach, therefore, can inform the judicial implementation of South Africa's project of transformative constitutionalism, and contribute to the formulation of effective relief

13 E Mureinik 'A Bridge to where? Introducing the interim Bill of Rights' (1994) 10 South African Journal on Human Rights 3132.

14 See Van der Berg (2015) (n 8).

15 Van der Berg (2017) (n 8) 576.

16 P Langa 'Transformative constitutionalism' (2006) 17 Stellenbosch Law Review 351 354; S Liebenberg Socio-economic rights: Adjudication under a transformative constitution (2010) 2932.

17 Sen (1999) (n 3) 56-57, 110, 274, 284; Sen (2009) (n 3) 44.

18 Mureinik (n 13) 32; M Pieterse 'What do we mean when we talk about transformative constitutionalism?' (2005) 20 South African Public Law 155156161 165; Langa (n 16) 353.

19 Sen (1999) (n 3) 30, 75; Sen (2009) (n 3) 4 109-110.

20 S Fredman Human rights transformed: Positive rights and positive duties (2008) 109; Sen (2009) (n 3) 107. 
where socio-economic rights are infringed on a systemic level through unreasonable resource allocation.

\subsection{Remedial powers under the Constitution}

The South African judiciary enjoys wide remedial powers under the Constitution. Anyone who enjoys locus standi in terms of the broad provision in section 38 'has the right to approach a competent court, alleging that a right in the Bill of Rights has been infringed or threatened, and the court may grant appropriate relief, including a declaration of rights' ${ }^{21}$ Where a socio-economic right is infringed by a resource allocation decision, courts are empowered to grant 'appropriate' relief. A capabilities approach to remedies implies that 'appropriate' relief must be relief aimed at the realisation of the capabilities which the relevant infringed socio-economic right protects. $^{22}$ The Constitution and a capabilities approach to adjudication justify the judiciary's remedial competence, even where relief calls for increased resource allocation, or for institutional reform in order to ensure effective resource allocation. ${ }^{23}$ Section 172 of the Constitution expands on the remedial powers of the courts:

(1) When deciding a constitutional matter within its power, a court -

(a) must declare that any law or conduct that is inconsistent with the Constitution is invalid to the extent of its inconsistency; and

(b) may make any order that is just and equitable, including -

(i) an order limiting the retrospective effect of the declaration of invalidity; and

(ii) an order suspending the declaration of invalidity for any period and on any conditions, to allow the competent authority to correct the defect.

Where resource allocation is disproportionate to the socio-economic capabilities at stake, the unjustifiable infringement of a socioeconomic right occurs. Courts are obliged under section 172(1)(a) to declare such allocative decision invalid. However, a declaration of invalidity runs the risk of leading to polycentric results. It would accordingly be 'just and equitable' to suspend such a declaration of invalidity $^{24}$ and to couple such order with a structural interdict ${ }^{25}$ to allow government to formulate a plan to rectify an unconstitutional resource allocation decision and thereby fulfil the infringed socioeconomic right. By conceptualising of the structural interdict as a flexible remedy that grants the state leeway to conceive suitable

\footnotetext{
21 Sec 38 Constitution.

22 For the relationship between capabilities and functionings, see Sen (1999) (n 3) 75.

23 Sen (1999) (n 3) 141-143.

24 Sec 172(1)(b)(ii) Constitution.

25 For the potential of the structural interdict to mitigate polycentric effects and effect capability realisation, see further part 3.2 below.
} 
remedial plans, relief of this nature may deter courts from invoking the separation of powers doctrine to limit their remedial obligations. ${ }^{26}$

\subsection{Remedial approach of the Constitutional Court in qualified socio-economic rights cases}

Where qualified socio-economic rights are at issue, the availability of resources - and the reasonableness of allocative decisions - always are of central significance. This is due to the fact that the rights of access to adequate housing, health care services, sufficient food and water, and social assistance, are all subject to the constitutional qualification that the state should take reasonable measures, within its available resources, to progressively realise each of these rights. ${ }^{27}$ Therefore, it is instructive to analyse the Constitutional Court's approach to remedies where complex, polycentric matters of resource allocation were at issue.

\subsubsection{The potential inefficiency of declaratory orders}

In Government of the Republic of South Africa $v$ Grootboom ${ }^{28}$ (Grootboom case), the Court issued a declaratory order regarding the constitutional shortcomings of the state's housing policy. ${ }^{29}$ This judgment thus is a prime example of pitfalls that may accompany the issuing of declaratory orders where systemic shortcomings go beyond mere government inattentiveness in formulating socio-economic policy. ${ }^{30}$ In terms of the declaratory relief issued, the Court held that '[s]ection 26(2) of the Constitution requires the state to devise and implement within its available resources a comprehensive and coordinated programme progressively to realise the right of access to adequate housing'. ${ }^{31}$ Regrettably, the order was not expeditiously implemented and a delay of over three years ensued before the state devised a revised housing policy that catered for those in urgent need. $^{32}$ During this period all persons 'in desperate need' ${ }^{\prime 33}$ of

26 CC Ngang 'Judicial enforcement of socio-economic rights in South Africa and the separation of powers objection: The obligation to take "other measures"' (2014) 14 African Human Rights Law Journal 655.

27 Secs 26(2) and 27(2) of the Constitution both qualify the various socio-economic rights set out in secs $26(1)$ and $27(1)$, respectively.

282001 (1) SA 46 (CC).

29 The Constitutional Court previously made the negotiated settlement between the parties an order of court, dated 21 September 2000 (on file with author) which was implemented to a certain extent. K Pillay 'Implementing Grootboom: Supervision Needed' (2002) 3 ESR Review 13 14; Liebenberg (n 16) 401.

30 For the circumstances in which declaratory orders may constitute effective relief, and for further examples of the use of declaratory orders by South African courts, see P Swanepoel 'The potential of structural interdicts to constitute effective relief in socio-economic rights cases' unpublished LLM dissertation, University of Stellenbosch, 2017 64-69.

31 Grootboom (n 28) para 99.

32 Liebenberg (n 16) 401-403.

33 Grootboom (n 28) para 52. 
temporary housing continued to live in 'intolerable conditions', 34 without access to any type of shelter. It is clear that in such conditions severe basic capability deprivation occurs. ${ }^{35}$ Not even elementary functioning outcomes, ${ }^{36}$ such as possessing adequate shelter, enjoying basic services or attaining a basic state of good health, can be achieved in such circumstances. In this case, a capabilities approach to a remedy would thus have required the participation of all stakeholders to identify the capability needs at stake and respond accordingly. Moreover, the retention of supervision may have helped to ensure that the state revised its programme expeditiously. The retention of supervision would have been justified in light of the grave capability deprivation that occurred in the absence of provision for emergency housing relief.

\subsubsection{A reluctance to retain supervision}

Subsequently, in Minister of Health $v$ Treatment Action Campaign (No 2)

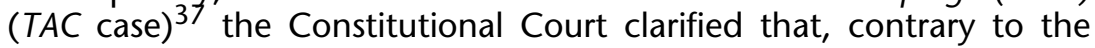
state's arguments, courts are not limited to issuing declaratory orders only: 38

There is ... no merit in the argument advanced on behalf of government that a distinction should be drawn between declaratory and mandatory orders against government. Even simple declaratory orders against government or organs of state can affect their policy and may well have budgetary implications. Government is constitutionally bound to give effect to such orders whether or not they affect its policy and has to find the resources to do so.

In terms of $T A C$, courts are therefore empowered to grant orders that affect policy and resource allocation, ${ }^{39}$ while remaining sensitive to the institutional roles of the different branches of government under the separation of powers doctrine. ${ }^{40}$ According to the Court, where the nature of the right infringed, the nature of the infringement ${ }^{41}$ and the circumstances of the particular case so demand, 'courts may - and if need be must - use their wide powers to make orders that affect policy as well as legislation'. ${ }^{42}$ The Court concluded that structural

\section{As above.}

35 Sen (1999) (n 3) 20 perceives poverty as constituting basic capability deprivation.

36 'Functionings' represent achievements or what a person can actually do, whereas capability sets represent the substantive freedom to choose different functioning combinations. Capabilities, therefore, constitute the real opportunities that people have to realise various lifestyles, rather than the choices they actually make. 'Functionings' represent a supple concept, which can include basic states of being (eg being adequately nourished) as well as more complex states of being (eg being able to participate effectively in community life). Sen (1999) (n 3) 75.

372002 (5) SA 721 (CC).

38 TAC (n 37) para 99 (my emphasis).

39 TAC para 99.

40 TAC para 113.

41 TAC para 106.

42 TAC para 113. 
interdicts do not breach the separation of powers doctrine, 'particularly when the state's obligations are not performed diligently and without delay'. ${ }^{43}$

However, in issuing declaratory and mandatory orders, the Court again declined to retain supervisory jurisdiction, stating that a structural interdict was unnecessary since 'government has always respected and executed orders' of the Court. ${ }^{44}$ TAC concerned government policy in respect of the provision of anti-retroviral medication to HIV positive, pregnant mothers, and thus engaged the right of access to adequate health care services. Given the delayed implementation of a revised housing policy in Grootboom, and certain provinces' recalcitrance in implementing the orders made in $T A C_{1}^{45}$ the Court's reluctance to issue a structural interdict was inapt. In casu, the failure to provide immediate and effective relief would lead to the deaths of a significant number of HIV-infected infants and the capability deprivation of an exceptionally vulnerable group (infants) would be absolute. The urgent necessity of protecting these vital capabilities, therefore, would have justified a capabilities approach to a remedy in the form of a structural interdict.

\section{Overcoming the judicial reluctance to issue structural interdicts in qualified socio-economic rights cases}

\subsection{Constitutional and institutional competence}

From the above discussion it emerges that the Constitutional Court has been reluctant to grant structural remedies (or to delegate this function to the High Courts) in cases where qualified socio-economic rights were at issue. ${ }^{46}$ Instead, the Court has seemingly conceptualised the structural interdict as a 'remedy of last resort' 47

43 TAC para 112

44 TAC para 129. This judgment is illustrative and not the only instance where a South African court has declined to retain jurisdiction.

45 K Roach \& G Budlender 'Mandatory relief and supervisory jurisdiction: When is it appropriate, just and equitable' (2005) 122 South African Law Journal 325 333-334; C Hoexter Administrative law in South Africa (2012) 562-563.

46 In contrast, the Constitutional Court has issued supervisory remedies in cases where the unqualified right to education, enshrined in sec 29(1)(a) of the Constitution, was at stake. Governing Body of the Juma Musjid Primary School $v$ Essay NO 20118 BCLR 761 (CC). The Court has also asserted its competence to issue mandatory orders and retain supervision in cases where civil and political rights were at stake. See August v Electoral Commission 1999 (3) SA 1 (CC); Minister of Home Affairs v National Institute for Crime Prevention 2005 (3) SA 280 (CC) (voting rights of prisoners) and Sibiya $v$ Director of Public Prosecutions: Johannesburg 2005 (5) SA 315 (CC) (replacement of death sentences with appropriate forms of punishment). 
only to be granted 'where governments are incompetent or intransigent with respect to the implementation of rights'. ${ }^{48}$

\subsubsection{Judicial responsibility for the granting of effective relief}

Davis ascribes the judicial reluctance to grant managerial remedies where qualified socio-economic rights are concerned to the same factor arguably responsible for the Court's resort to a 'proceduralised', normatively weak model of reasonableness review, 49 namely, the Court's hesitancy to encroach upon the terrain of the executive or legislative branches of government. ${ }^{50}$ The Supreme Court of Appeal has also voiced its separation of powers-based concerns regarding the structural interdict: ${ }^{51}$

Structural interdicts ... have a tendency to blur the distinction between the executive and the judiciary and impact on the separation of powers. They tend to deal with policy matters and not with the enforcement of particular rights ... Then there is the problem of sensible enforcement: the state must be able to comply with the order within the limits of its capabilities, financial or otherwise.

However, it must be borne in mind that the separation of powers allocates adjudicative responsibility to the judiciary. This includes the power to grant effective remedies. In Allpay II, in which the Constitutional Court issued what it termed a structural interdict ${ }^{52}$ in respect of the running of a new tender process for the payment of social security grants, the Court emphasised this point: ${ }^{53}$

There can be no doubt that the separation of powers attributes responsibility to the courts for ensuring that unconstitutional conduct is declared invalid and that constitutionally mandated remedies are afforded for violations of the Constitution. This means that the Court must provide effective relief for infringements of constitutional rights.

48 Roach \& Budlender (n 45) 327. Rail Commuters Action Group v Transnet Ltd t/a Metrorail 2005 (2) SA 359 (CC) para 109.

49 D Brand 'The proceduralisation of South African socio-economic rights jurisprudence, or "What are socio-economic rights for?"' in H Botha, A van der Walt \& J van der Walt (eds) Rights and democracy in a transformative constitution (2003) 33.

50 D Davis 'Adjudicating the socio-economic rights in the South African Constitution: Towards "Deference Lite"?' (2006) 22 South African Journal on Human Rights 301 311. See further S van der Berg 'Meaningful engagement: Proceduralising socioeconomic rights further or infusing administrative law with substance?' (2013) 29 South African Journal on Human Rights 376382.

51 Modder East Squatters $v$ Modderklip Boerdery (Pty) Ltd, President of the Republic of South Africa v Modderklip Boerdery (Pty) Ltd 20043 All SA 169 (SCA) (Modderklip) para 39.

52 Allpay II (n 1) para 71.

53 Allpay II para 42. 


\subsubsection{The structural interdict as an effective and participatory remedy}

The structural interdict potentially embodies an effective and participatory remedy that can overcome traditional concerns that courts lack the constitutional and institutional competence required to adjudicate complex resource allocation decisions. By accommodating these concerns at the remedial stage of adjudication, the need for deference in applying a capabilities-based standard of review to allocative decisions is obviated.

Legitimacy concerns are mitigated by conceptualising the structural remedy as a dialogic engagement among all stakeholders, including the legislature. Stakeholders thus express their agency through participation, and simultaneously influence the formulation of public policy that can potentially lead to new legislation. This possibility was recognised in Doctors for Life International $v$ Speaker of the National Assembly ${ }^{54}$ in the context of participation in the legislative process: ${ }^{55}$

The participation by the public on a continuous basis provides vitality to the functioning of representative democracy ... It enhances the civic dignity of those who participate by enabling their voices to be heard and taken account of. It promotes a spirit of democratic and pluralistic accommodation calculated to produce laws that are likely to be widely accepted and effective in practice. It strengthens the legitimacy of legislation in the eyes of the people.

Furthermore, a structural interdict affords leeway to the executive to design a plan for the procurement of additional resources aimed at capability realisation, or for the effective implementation of existing allocations. ${ }^{56}$ Besides the government's recalcitrance in adhering to court orders or cases where non-compliance would cause irremediable damage, ${ }^{57}$ Roach and Budlender identify a third situation where the structural interdict would be appropriately granted. According to the authors, courts should feel fortified in granting a managerial remedy where a mandatory order is stated in general terms, due to the nature of the duty involved ${ }^{58}$ or the need to grant the state as much latitude as possible to devise its own plan. ${ }^{59}$ This may be the case where

542006 (6) SA 416 (CC).

55 Doctors for Life International (n 54) para 115.

56 Roach \& Budlender ( $n$ 45) 334.

57 Where basic capability deprivation occurs due to unreasonable resource allocation, non-compliance with a court order will potentially lead to irremediable damage. Black Sash I (n 1) serves as an example of government recalcitrance and where non-compliance would have left millions of social grant beneficiaries destitute.

58 Eg to allocate 'reasonable' or 'proportionate' resources to the fulfilment of a socioeconomic right. However, see part 4.2 below regarding the importance of explicitness both in granting a structural interdict (explicitness on the part of the court) and complying therewith (explicitness on the part of the state).

59 Roach \& Budlender (n 45) 334. In Western Cape Forum for Intellectual Disability $v$ Government of the Republic of South Africa 2011 (5) SA 87 (WCC) the Court stated that '[s]uch relief ... is appropriate when the court does not wish to prescribe to the respondent the detail of what steps must be taken' (para 50). 
broad structural reform is necessary, or where the remediation of the law or conduct in question raises complex, polycentric issues. The authors explain the benefit of a structural interdict to the state in such instances: 60

It may provide governments with a timeline to follow. The approval of a plan by the court can allow the government to move forward with the implementation of its plan secure in the knowledge that implementation will constitute compliance with its obligations. The court can make an order which is as non-intrusive as possible on the choices which the elected government makes, because it can be secure in the knowledge that this will not be an invitation to non-compliance but rather an invitation to the government to formulate a plan in order to achieve compliance with the Constitution.

Allowing the state latitude ensures that the executive can devise a plan with which it can comply within the limits of its financial capacity. A capabilities-infused structural interdict, therefore, can complement a fluid conceptualisation of the separation of powers doctrine. ${ }^{61}$ Rodríguez-Garavito elaborates: 'Dialogic judgments tend to outline procedures and broad goals and, in line with the principle of separation of powers, place the burden on government agencies to design and implement policies. ${ }^{62}$

By affording the state the discretion to devise an allocative plan in consultation ${ }^{63}$ with a broad range of stakeholders, concerns regarding the judiciary's competence to review allocative decisions can be addressed at the remedial stage of adjudication.

\subsection{Polycentricity}

The polycentricity inherent in state resource allocation decisions is often highlighted as a bar to their justiciability. ${ }^{64}$ Nevertheless, in August the Constitutional Court held: 'We cannot deny strong actual claims timeously asserted by determinate people, because of the possible existence of hypothetical claims that might conceivably have been brought by indeterminate groups. ${ }^{65}$

Yet the potential of a decision to result in unknown ramifications for a complex web of other issues is increased in proportion to the range

60 Roach \& Budlender (n 45) 334.

61 Liebenberg (n 16) 436; CF Sabel \& WH Simon 'Destabilisation rights: How public law litigation succeeds' (2004) 117 Harvard Law Review 10161090.

62 C Rodríguez-Garavito 'Beyond the courtroom: The impact of judicial activism on socio-economic rights in Latin America' (2011) 89 Texas Law Review 16691691.

63 See part 4.1 below.

64 L Fuller 'The forms and limits of adjudication' (1978) 92 Harvard Law Review 353 394. Resource allocation decisions are polycentric, since a judgment on a specific instance of resource allocation could result in unforeseen consequences for other budgetary allocations. Unforeseen consequences for budgetary allocations could result where groups in need of resources are left unrepresented in litigation. 
of interests not represented before a court. ${ }^{66}$ At the remedial stage of adjudication, '[f]airness requires a consideration of the interests of all those who might be affected by the order'. ${ }^{67}$ However, given that increased budgetary allocation can impact on different votes in the national budget and even on the macro-economic obligations of the state, it will seldom be possible to accommodate all the interests at stake. Nevertheless, the emphasis that a capabilities approach to adjudication places on informational broadening can significantly extend the scope of represented interests. ${ }^{68}$ The information available to the court for the formulation of an appropriate remedy can be expanded through, for example, the use of amicus curiae interventions or the consideration of other expert evidence. An even wider array of perspectives can be incorporated into remedial design by requiring the state to engage with a broad range of stakeholders and report back to the court.

Moreover, the latitude afforded to the state to formulate a constitutionally compliant allocative plan, coupled with the retention of supervision, promotes the flexibility needed to cater for adjustments in light of the materialisation of initially unforeseen consequences. The Constitutional Court has observed that 'any planning which leaves no scope whatsoever for relatively marginal adjustments in the light of evolving reality, may often not be reasonable'.69 The polycentric nature of resource allocation decisions can therefore be accommodated by the granting of structural interdicts which allow for changes in allocative plans as circumstances change.

Sabel and Simon further point out the capacity of 'experimentalist' remedies, including structural interdicts, to deal with polycentric effects as they arise: ${ }^{70}$

Just as the court's liability determination destabilizes relations and practices within the defendant institution, so does it ramify to other institutions and practices. These ramifications ... are the web effect. The web effect makes it possible to address sequentially - in a sequence determined in the course of problem-solving itself - reforms too complex to be addressed whole. This effect is polycentricity viewed as an aid, not an obstacle, to problem solving.

The retention of supervision therefore allows a court to modify its orders sequentially, as circumstances change or initially unavailable information comes to light. Without the retention of supervision and the establishment of a dialogic relationship between the court and other branches of government, unforeseen consequences of a particular court order cannot be accommodated. A traditional

66 C Mbazira 'Confronting the problem of polycentricity in enforcing socio-economic rights in the South African Constitution' (2008) 23 South African Public Law 3041.

67 Hoffmann $v$ South African Airways 2001 (1) SA 1 (CC) para 43 (my emphasis).

68 See part 4.1 below.

69 Modderklip (n 51) para 49.

70 Sabel \& Simon (n 61) 1080. 
remedy, such as a simple mandatory order without the retention of supervision, does not allow for similar flexibility. However, the flexibility inherent in the structural interdict must be combined with explicit normative parameters, set by the court, in order to ensure constitutional resource allocation decisions. ${ }^{71}$

\section{A capabilities approach to remedies}

A capabilities approach to remedies posits that where the infringement of a socio-economic right entails the deprivation of critical capabilities, a remedy that can effectively vindicate those capabilities is required. Whereas the remedy will thus be directed at remediating the infringement of the socio-economic right, its effectiveness can be measured by its success in realising the capabilities underlying the right.

The structural interdict can be designed so as to incorporate three capabilities-based features that are mutually reinforcing and conducive to effective relief: First, the structural interdict can facilitate participation by a wide range of stakeholders. Second, any order that compels the state to engage with stakeholders and respond accordingly can be accompanied by explicit normative guidelines that outline the broad contours of what proportionate resource allocation may necessitate. Finally, the retention of supervision will allow the court to monitor compliance with its orders, and to revise its orders as needed in light of the challenges identified by an ongoing process of participation.

All three features of a capabilities approach to the structural interdict are mutually supporting and combine to encapsulate an effective remedy. The features will thus overlap with each other during the remedial process. First, a court will facilitate participation prior to issuing an initial order. The first order will be accompanied by explicit normative guidelines. A process of participation will then continue among the state and various other stakeholders. The results of the participatory process may in turn require the court to adapt its initial normative guidelines. The retention of supervision makes an ongoing process of participation and the revision of orders possible.

\subsection{Participation and informational broadening}

Under South African's transformative Constitution, participation should be promoted in all spheres of government and in any decision that may have an impact on rights. ${ }^{72}$ Participation thus is a key foundational requirement that should be facilitated by the judiciary as

71 For a discussion regarding the importance of explicit, normative parameters in granting a structural remedy, see part 4.2 below.

72 Klare (n 11) 155; D Brand 'Judicial deference and democracy in socio-economic rights cases in South Africa' (2011) 22 Stellenbosch Law Review 614 622-623. 
part of a collaborative partnership with other branches of the state, ${ }^{73}$ aimed at the realisation of the ideals encapsulated by the Constitution. Participation is also a central tenet of a capabilities approach to adjudication, in that it fosters the agency of those whose capabilities are affected by state allocative decisions. ${ }^{74}$ Participatory capabilities $^{75}$ are intrinsically valuable. They are also instrumentally important in that participation can shape the government's allocative policy and so lead to the realisation of other capabilities that are prerequisites for meaningful participation in the social, economic and political milieu.

The informational base used for making evaluative judgments, likewise, is of central significance to the capabilities theory. ${ }^{76}$ Thus, a capabilities approach to adjudication uses the informational base of capabilities as the measure against which resource allocation as well as remedial effectiveness can be judged. For remedial action to be effective, capability needs in a given contextual setting as well as the potential means for meeting such needs must be identified. The information must be sufficient to demonstrate the costs of remedying capability deprivation, as well as the resources potentially at the state's disposal for this purpose. The information available to a court and the state for the formulation and implementation of a remedy must thus be broadened to the greatest extent practicable.

A capabilities approach to the emphasis of remedies on informational broadening through participatory processes resonates strongly with Rodríguez-Garavito's proposal for strongly interpreted rights, dialogic remedies and strong monitoring: ${ }^{77}$

Dialogic decisions tend to open a monitoring process that encourages discussion of policy alternatives to solve the structural problem detected in the ruling ... the minutiae of the policies arise during the course of the monitoring process, not in the judgment itself ... [T] his constitutional dialogue involves a broader spectrum of stakeholders in the monitoring process. In addition to the court and state agencies directly affected by the judgment, implementation involves victims whose rights have been violated, relevant civil-society organizations, international human rights agencies, and other actors whose participation is useful.

It is thus through a process of informational broadening - starting in the courtroom, ${ }^{78}$ expanding to other stakeholders and returning to

73 For a discussion of a collaborative partnership between all branches of government in the Indian context, see People's Union for Democratic Rights $v$ Union of India 19831 SCR 456469.

74 For the importance of agency, see Sen (1999) (n 3) 19 38-41 53.

75 Participatory capabilities are those related to social, economic and political participation.

76 For the importance of informational broadening and participation, see Sen (1999) (n 3) 56-57.

77 Rodríguez-Garavito (n 62) 1691-1692.

78 Participation should be observed in the exercise of all public power, including the drafting of legislation and formulation of policies related to resource allocation. Minister of Health $v$ New Clicks South Africa (Pty) Ltd (Treatment Action Campaign as Amicus Curiae) 2006 (2) SA 311 (CC) para 625. Participation in the allocative 
the courtroom for approval and normative guidance - that capabilities-focused allocative choices can be ensured.

\subsubsection{Informational broadening in the courtroom}

Informational broadening must commence in court in order to effectively apply a capabilities-based standard of review, and to formulate an appropriate remedy aimed at achieving proportionate resource allocation. Where relevant capabilities and interests are not considered, allocative policy may remain under-inclusive or ineffective. By assimilating a multitude of perspectives, the formulation of an effective remedy directed at proportionate resource allocation is possible. $^{79}$

One way in which the judiciary can initiate the process of informational broadening is to direct the joinder of all relevant parties. Joinder will be appropriate where a party has a substantial interest in the matter. ${ }^{80}$ Joinder furthermore can circumvent problems related to legitimacy and institutional competence by allowing relevant organs of state to participate in matters within their expertise. ${ }^{81}$ By citing the national and provincial governments at the initiation of the proceedings, provision can be made for the inclusion of all relevant organs of state while fostering intergovernmental participation and accountability. ${ }^{82}$ The non-joinder of parties with an interest in the adjudication of state resource allocation decisions can thus have a critical bearing on the possibility of an effective remedy. ${ }^{83}$

Another way in which informational broadening can occur in the courtroom is by drawing from the Indian Supreme Court's experience in appointing commissions to provide information, help in the design of remedies and monitor implementation where necessary. ${ }^{84}$ The Constitutional Court recently appointed a panel of experts to monitor

process will thus be one factor a court should consider in applying a capabilitiesbased standard of review. Once a resource allocation decision is found to be unreasonable or disproportionate, thus infringing a socio-economic right, participation as informational broadening again becomes crucial.

79 Mbazira (n 66) 43.

80 G Muller 'The impact of section 26 of the Constitution on the eviction of squatters in South African law' unpublished LLD thesis, University of Stellenbosch, 2011 231. See further G Muller \& S Liebenberg 'Developing the law of joinder in the context of evictions of people from their homes' (2013) 29 South African Journal on Human Rights 554.

81 Mabaso v Law Society, Northern Provinces 2005 (2) SA 117 (CC) para 13.

$82 \mathrm{Eg}$, 'the government of the Republic of South Africa' and the 'Premier of the Province of the Western Cape' were cited in Grootboom (n 28). A similar approach was followed in Madzodzo v Minister of Basic Education 2014 (3) SA 441 (ECM).

83 Rule 8(1) of the Rules of the Constitutional Court GN R1675 in GG 25726 of 31 October 2003 states: 'Any person entitled to join as a party or liable to be joined as a party in the proceedings may, on notice to all parties, at any stage of the proceedings apply for leave to intervene as a party.'

84 PN Bhagwati 'Judicial activism and public interest litigation' (1985) 23 Columbia Journal of Transnational Law 561 575-577; J Cassels 'Judicial activism and public interest litigation in India: Attempting the impossible?' (1989) 37 American Journal of Comparative Law 495500506. 
the payment of social grants and SASSA's progress in making adequate arrangements for the distribution of social grants in the future. 85

In addition, amicus curiae interventions constitute a valuable mechanism for broadening the information available to the reviewing court and the state in order to formulate effective remedies. ${ }^{86}$ An amicus curiae 'acts in the interests of the broader society rather than of specific individuals, focusing on the broader implications of a case' ${ }^{87}$ Amici curiae can thus alert the court and state to any overlooked and unrepresented interests. They may also identify at least some of the polycentric effects that might result from ordering the state to devise and implement reasonable allocative decisions. ${ }^{88}$ In Allpay II the Constitutional Court highlighted the multi-dimensional approach necessary to formulate a 'just and equitable' remedy and the Court's inability to identify all the interests that may be affected by its order. ${ }^{89}$ In casu, one of the amici curiae's submissions that any order made should not result in the interruption of social grants was duly noted by the Court. ${ }^{90}$ The amicus curiae, therefore, brought the capabilities of the unrepresented grant beneficiaries squarely into focus for the Court to consider in formulating an appropriate remedy.

Courts may further utilise provisions that allow for the appointment of expert referees with the consent of the parties in technical, complex and polycentric matters such as those related to resource allocation. $^{91}$ The findings of such referees can subsequently be incorporated into the normative guidelines issued by a court along with a participatory remedy and the retention of supervision. Finally, courts can order the formulation of specialised task forces to investigate the allocative needs of litigants and those similarly placed, in order for any resultant resource allocation decision to be proportionate to the capability needs thus identified. ${ }^{92}$

85 SASSA (n 1).
86 Rule 10 of the Rules of the Constitutional Court GN R1675 in GG 25726 of
31 October 2003 makes provision for amicus curiae interventions.
87 L Chenwi 'Litigating socio-economic rights through amicus briefs' (2009) 10 ESR
Review 78 .
88 See further Fose $v$ Minister of Safety and Security 1997 (3) SA 786 (CC) para 9; Hoffmann (n 67) para 63; M Heywood 'Debunking "conglomo talk": A case study of the amicus curiae as an instrument for advocacy, investigation and mobilisation' (2001) 5 Law, Democracy and Development 133.

89 Allpay II (n 1) paras 39-40.

90 Allpay II para 27.

91 Sec 19bis of the Supreme Court Act 59 of 1959; J Fowkes 'How to open the doors of the court: Lessons on access to justice from Indian PIL' (2011) 27 South African Journal on Human Rights 434 457; D Butterworth, J d'Oliviera \& C de Moor 'Are South African administrative law procedures adequate for the evaluation of issues resting on scientific analyses?' (2012) 129 South African Law Journal 461476 n 42.

92 See Madzodzo (n 82), where a dedicated Furniture Task Force was established in order to identify the furniture needs of the relevant schools. This enabled an estimation of the budgetary resources required to meet said needs. 


\subsubsection{Informational broadening among the state and other stakeholders}

In addition to fostering participation in the courtroom, courts can issue participatory remedies in combination with explicit normative guidelines and the retention of supervision. ${ }^{93}$ One of the most promising developments in socio-economic rights jurisprudence is the innovation of requiring meaningful engagement both as a prerequisite for reasonable socio-economic policy and as a remedy in appropriate cases. ${ }^{94}$ In Port Elizabeth Municipality $v$ Various Occupiers ${ }^{95}$ Sachs J stated: ${ }^{96}$

[T] he procedural and substantive aspects of justice and equity cannot always be separated. The managerial role of the courts may need to find expression in innovative ways. Thus one potentially dignified and effective mode of achieving sustainable reconciliations of the different interests involved is to encourage and require the parties to engage with each other in a pro-active and honest endeavour to find mutually acceptable solutions.

Meaningful engagement was first utilised as a remedy in Occupiers of 51 Olivia Road, Berea Township and 197 Main Street, Johannesburg v City of Johannesburg. ${ }^{97}$ In this case the Constitutional Court issued an interim order for the City of Johannesburg to engage meaningfully with potential evictees from buildings that posed a health and safety risk. The Court linked the duty to engage meaningfully with several constitutional duties owed to occupiers that are intricately connected to the fundamental rights of dignity and life. ${ }^{98}$

Meaningful engagement has also been ordered as part of a structural interdict at the High Court level. In NAWONGO $1^{99}$ the

93 Van der Berg (n 50). Participatory remedies must be preceded by strong, substantively interpreted rights during the application of a capabilities-based standard of review. Rodríguez-Garavito (n 62) 1691-1692.

94 B Ray 'Proceduralisation's triumph and engagement's promise in socio-economic rights litigation' (2011) 27 South African Journal on Human Rights 107 116-120 argues that engagement, if properly developed and institutionalised, can constitute an effective tool for the poor with which to vindicate their socioeconomic rights. Once institutionalised, an order of meaningful engagement will gradually become less resource intensive.

952005 (1) SA 217 (CC). The remedy of meaningful engagement was foreshadowed in Grootboom (n 28) para 87.

96 Port Elizabeth Municipality (n 95) para 39.

972008 (3) SA 208 (CC).

98 Occupiers of 51 Olivia Road (n 97) para 16.

99 National Association of Welfare Organisations and Non-Governmental Organisations v MEC for Social Development (1719/2010) [2010] ZAFSHC 73 (5 August 2010) (NAWONGO 1). Three further orders were made: National Association of Welfare Organisations and Non-Governmental Organisations v MEC for Social Development (1719/2010) [2011] ZAFSHC 84 (9 June 2011) (NAWONGO 2); National Association of Welfare Organisations and Non-Governmental Organisations v MEC for Social Development, Free State (1719/2010) [2013] ZAFSHC 49 (28 March 2013) (NAWONGO 3); and National Association of Welfare Organisations and NonGovernmental Organisations $v$ Member of the Executive Council for Social Development, Free State (1719/2010) [2014] ZAFSHC 127 (28 August 2014) (NAWONGO 4) where the allocative policy was finally upheld as constitutional. 
Court issued a structural interdict aimed at bringing the Free State Department of Social Development's funding policy for the funding of non-profit organisations (NPOs) that provide social welfare services to those in need in the province in line with its constitutional and statutory obligations. In NAWONGO 2 the Court ordered the state to meaningfully engage with the under-funded NPOs in order to bring its funding policy in line with its constitutional obligations. ${ }^{100}$ However, when NAWONGO 3 came before the Court, the state had not complied with the engagement order. The state's failure to engage with the NPOs and thereby broaden the information available to it was consequently reflected in its still constitutionally deficient funding policy. In castigating the state for its non-compliance, the Court emphasised that '[m] eaningful engagement is a minimum required for formulating social welfare policy ${ }^{\prime 101}$ and, as the facts of the case show, for socio-economic allocative policies as well. One factor leading to the ineffective design of a constitutional allocative policy in this case was thus likely the state's failure to engage with a broad range of stakeholders.

Meaningful engagement thus can be used as a mechanism to identify which capabilities are at stake. Once this information is known, allocative decisions can be revised accordingly.

\subsubsection{Informational broadening within different spheres and organs of state}

In Grootboom the need for co-operation between different spheres of government in their efforts to realise socio-economic rights was highlighted. ${ }^{102}$ As observed by Pillay, a breakdown in communication between different spheres of government following the order in Grootboom resulted in uncertainty regarding who bore the responsibility for resource allocation, and consequently in ineffective allocative decisions. ${ }^{103}$ The requirement for informational broadening therefore requires different spheres of government and organs of state to co-operate and share information.

The duty of different organs of state to co-operate inter se has subsequently been emphasised by the Constitutional Court in several cases in which the right to education was implicated. ${ }^{104}$ In Rivonia Primary School'105 the Court repeated the need for 'proper

100 NAWONGO 2 (n 99) para 28 order 2.

101 NAWONGO 3 (n 99) para 15.

102 Grootboom (n 28) para 68.

103 K Pillay 'Implementation of Grootboom: Implications for the enforcement of socioeconomic rights' (2002) 6 Law, Democracy and Development 255 267-268.

$104 \mathrm{Sec} 29$ of the Constitution. Head of Department, Department of Education, Free State Province $v$ Welkom High School; Head of Department, Department of Education, Free State Province v Harmony High School 2014 (2) SA 228 (CC); MEC for Education in Gauteng Province \& Others v Governing Body of Rivonia Primary School 2013 (6) SA 582 (CC).

105 Rivonia Primary School (n 104). 
engagement between all parties affected', 106 and highlighted 'the damage that results when some functionaries fail to take the general obligation to act in partnership and co-operation seriously'. ${ }^{107}$ Intergovernmental co-operation where complex, polycentric resource allocation decisions are concerned is of similarly critical importance. This is confirmed by the very raison d'être of the Intergovernmental Fiscal Relations Act 97 of 1997, the purpose of which is stated to be ' $\mathrm{t}$ ] $\mathrm{o}$ promote co-operation between the national, provincial and local spheres of government on fiscal, budgetary and financial matters' ${ }^{108}$ When different departments of state need to engage with each other on macro-economic matters in order to remediate unreasonable resource allocation decisions, ${ }^{109}$ informational broadening among different spheres of government and organs of state becomes imperative in terms of a capabilities approach to remedies. ${ }^{110}$

Participation at the remedial stage of adjudication thus fosters the fundamental constitutional values of openness and responsiveness, 111 while forming an indispensable component of a capabilities approach to remedies. To furthermore foster the value of accountability and promote a culture of justification, a capabilities approach to remedies additionally requires explicitness.

\subsection{Explicitness}

A capabilities approach to the adjudication of state resource allocation decisions demands explicit reasoning when making evaluative judgments regarding the weighting and prioritisation of diverse capabilities and other interests. ${ }^{112}$ Explicitness in the adjudicative process further resonates with the demands of a culture of justification under South Africa's transformative Constitution. ${ }^{113}$ Explicit normative parameters can aid the state in understanding its constitutional obligations and enable it to devise an effective allocative plan. By also requiring the state to explicitly indicate its progress in formulating and implementing a remedial plan, accountability is fostered. In Magidimisi

106 Rivonia Primary School para 72.

107 Rivonia Primary School para 74. S Liebenberg 'Deepening democratic transformation in South Africa through participatory constitutional remedies' (2015) National Journal of Constitutional Law (forthcoming).

108 Preamble to the Intergovernmental Fiscal Relations Act.

109 See Basic Education for All v Minister of Basic Education 2014 (4) SA 274 (GP) para 80 where the Court acknowledged that, while difficult, a case could arguably be made to challenge vote allocations in the national budget.

110 The involvement of, eg, the National Treasury where critical socio-economic capabilities are imperilled by unreasonable resource allocation is of crucial importance. See, eg, Madzodzo (n 82) para 3; Treasury Regulations GN R556 in GG 21249 of 31 May 2000 as amended by GN R225 in GC 27388 of 15 March 2005.

111 Sec 1(d) Constitution.

112 Sen (1999) (n 3) 75. For the importance of explicitness under a transformative constitution, see Van der Berg (2017) (n 8) 576.

113 Mureinik (n 13) 32; Pieterse (n 18) 156, 161, 165. 
NO $v$ The Premier of the Eastern Cape $e^{114}$ the High Court elucidated the benefits of structural interdicts: ${ }^{115}$

[Structural interdicts] have contributed to a better understanding on the part of public authorities of their constitutional legal obligations in particular areas, whilst it has also assisted the judiciary in gaining a valuable insight in the difficulties that these authorities encounter in their efforts to comply with their duties.

To constitute a capabilities approach to remedies, explicitness should therefore be observed both by a court in granting a structural interdict and by the state in devising a new allocative plan subject to approval by the relevant court.

\subsubsection{Judicial explicitness}

A participatory remedy directed at informational broadening in itself may not constitute effective relief. A capabilities approach to remedies requires meaningful engagement and similar procedural remedies to be accompanied by explicit normative guidelines and the retention of judicial supervision. ${ }^{116}$ Liebenberg argues for the provision of explicit normative guidelines where meaningful engagement is ordered: 117

If not combined with sufficient normative interpretative guidance on what the particular constitutional right requires of the duty-bearers, other groups similarly placed may not be able to derive the systemic benefits which should flow from constitutional rights litigation ... The potential radiating benefits of constitutional litigation will not be generated as organs of state will be left with insufficient guidance regarding the normative parameters and objectives of engagement processes - parameters and objectives which should be inextricably linked to the substantive interests and values which the relevant rights were designed to protect.

By combining an explicit order with an ongoing process of participation and the retention of supervision, provision is also made for the adaptation of the order in light of information yielded by the process of engagement described above. Michelman explains revisability in the context of democratic experimentalism: ${ }^{118}$

As the discursive benchmarking moves along and the emerging answers gain public recognition and authorization, the court might turn up the heat on deployment of its powers of review. At a relatively early stage, what

1142006 JDR 0346 (B).

115 Magidimisi (n 114) para 32.

116 See Liebenberg ( $n$ 107). See further L Chenwi 'A new approach to remedies in socio-economic rights adjudication: Occupiers of 51 Olivia Road and Others $v$ City of Johannesburg and Others' (2009) 2 Constitutional Court Review 371 389-391 for criticism of the Constitutional Court's failure to set normative parameters and its 'sheer unwillingness' to make determinations on substantive issues in Olivia Road (n 98).

117 Liebenberg (n 107).

118 FI Michelman 'Constitutionally binding social and economic rights as a compelling idea: Reciprocating perturbations in liberal and democratic constitutional visions' in HA García, K Klare \& LA Williams (eds) Social and economic rights in theory and practice (2015) 277 288-289. 
the court presumes to dictate will be agendas of questions to be addressed and answered by one or another stakeholder group or class. At later stages, the court starts calling for substantive compliance with the emergent bestpractice standards ... The screws tighten on what can count as cogent or 'reasonable'. The court serves as arbiter but it never has or claims a doorclosing last word.

The need for the reassessment of initial judgments regarding the effective realisation of capabilities is also recognised by Sen, who acknowledges that initially unforeseen consequences may need to be addressed. $^{119}$ The requirements for explicitness and informational broadening through participatory processes thus dynamically interact with each other. This symbiotic relationship can be catered for by the ongoing nature of the structural interdict.

In its meaningful engagement jurisprudence, the South African Constitutional Court has sought to provide explicit parameters to guide the engagement between government and affected parties, especially in the housing context. In Residents of Joe Slovo Community, Western Cape $v$ Thubelisha Homes ${ }^{120}$ (Joe Slovo) the Court issued a detailed supervisory order that sought to regulate the minutia of the ultimate objects of the process of meaningful engagement in casu. As Ray observes, Joe Slovo enabled courts to control the meaningful engagement agenda. ${ }^{121}$

In Section $27 v$ Minister of Basic Education ${ }^{122}$ the High Court was approached in an attempt to solve the structural failure to realise the right to basic education in the Limpopo province. In casu, the widespread non-delivery of textbooks to schools was at issue. The Court commenced its judgment by elaborating the normative importance of the right to education. Importantly, the Court recognised that education was vital for people to be able to reach their potential, and contributed to the general upliftment of society. ${ }^{123}$ Having provided a rich normative framework for the adjudication of the matter at issue, the Court held that the Department of Basic Education's failure to deliver textbooks to schools in Limpopo constituted an infringement of the right to basic education. 124 The Court proceeded to grant the relief requested by the applicants in the form of a detailed structural interdict, which included ordering the department to devise a comprehensive remedial plan to address the severe educational shortcomings that resulted from a lack of textbooks. Without prescribing the content of the plan, the Court provided explicit guidelines outlining the contours

119 Sen (2009) (n 3) 106.

1202010 (3) SA 454 (CC).

121 Ray (n 95) 112. See further Van der Berg (n 50).

1222013 (2) SA 40 (GNP).

123 Section 27 (n 122) paras 1-4.

124 Section 27 para 32. 
of the plan. ${ }^{125}$ In providing these explicit guidelines, the Court's approach was wholly congruent with a capabilities approach to remedies. However, the department did not comply with the initial order and a further order was necessitated. Nonetheless, the implicit utilisation of a capabilities approach to remedies yielded valuable structural benefits such as the mobilisation of public opinion, shedding light on the crisis in education experienced in South Africa, and highlighting accountability and efficiency deficits in government. ${ }^{126}$

Even where state compliance cannot be guaranteed, a capabilities approach to remedies transforms a court into a deliberative platform where government action can be subjected to public scrutiny. Explicitness in the form of substantive, normative reasoning is critical for the promotion of meaningful public scrutiny, debate and subsequent mobilisation of non-judicial actors. A capabilities approach to remedies can thus facilitate structural reform, even if it is initially ineffective in extracting compliance from a recalcitrant government. $^{127}$

\subsubsection{State explicitness}

Just as a reviewing court should adhere to the capabilities tenet of explicit reasoning, the state also should explicitly indicate how its remedial allocative plan complies with a relevant court order. Hlophe $v$ City of Johannesburg Metropolitan Municipality ${ }^{128}$ is an example of the state failing to display explicitness in its remedial action. In this case the City of Johannesburg was obliged to provide alternative accommodation to residents of a privately-owned building prior to eviction. ${ }^{129}$ The matter came to be heard by Satchwell f following the City's non-compliance with two previous court orders. ${ }^{130}$ Both previous orders had required the City to provide detailed reports

125 F Veriava The 2012 Limpopo textbook crisis: A study in rights-based advocacy, the raising of rights consciousness and governance (2013) 38.

126 As above.

127 In contrast, when the issue of textbook delivery again came before the Court in Basic Education for All v Minister of Basic Education 2014 (4) SA 274 (GP), the Court declined to issue a structural interdict. Given the litigation history in this matter, the recalcitrance and intransigence of the Department and the implication of a fertile capability (the deprivation of which can have dire consequences for the freedom, dignity and equality of learners without textbooks), the Court's approach in casu eschews a capabilities approach to remedies and cannot be supported.

1282013 (4) SA 212 (GSI).

129 City of Johannesburg Metropolitan Municipality v Blue Moonlight Properties 39 (Pty) Ltd 2012 (2) SA 104 (CC) confirmed the state's obligation to provide alternative accommodation where people are evicted from privately-owned buildings.

130 Hlophe $v$ City of Johannesburg Metropolitan Municipality GSJ 12-06-2012 Case 20127/2011 and Hlophe $v$ City of Johannesburg Metropolitan Municipality GSJ 13-02-2013 Case 48103/2012 and 20127/2011. 
regarding the 'nature and location' of the temporary accommodation the City was obliged to provide. ${ }^{131}$ However, the City concluded in its first resulting report that it would be impossible for it to comply with the order to provide alternative accommodation due to 'the lack of available buildings and financial and other resources'. ${ }^{132}$ The second order $^{133}$ again required the City to file a further report, and stated in detail what information the report was to contain. ${ }^{134}$ When the City responded by filing another inadequate report, Satchwell J proceeded to condemn the lack of explicitness displayed by the City: ${ }^{135}$

[T] he City was ordered to detail certain specified information viz 'the nature and location of the accommodation to be provided'. This both reports failed to do. General elucidation of accommodation provided to other persons is of no assistance to the court; information about other buildings which are not available for use in housing these occupiers does not take resolution of this matter any further; mission and vision and policy development are irrelevant to the particular task ordered by the court; budgetary and asset constraints were not sought by the court.

The Court accordingly ordered a further report to be filed, and spelled out the minutiae of what the report should contain in the hope that explicit instructions 'might focus the minds of both politicians and functionaries on the work needed to be done by the City to meet its Constitutional obligations' ${ }^{136}$ The City finally responded by tendering alternative accommodation. ${ }^{137}$ Unfortunately, whereas recalcitrance on the part of the state is the most common justification for granting a structural interdict, neither explicitness - nor effectiveness - can always be extracted from intransigent officials.

The City subsequently lodged an appeal with the Supreme Court of Appeal claiming that a mandamus directing functionaries to perform their constitutional obligations is never appropriate. ${ }^{138}$ The Supreme Court of Appeal rejected this argument ${ }^{139}$ but proceeded to set aside the detailed reporting order issued by Satchwell J on the basis that only the nature and location of alternative accommodation were at issue before the court a quo. ${ }^{140}$ However, the Supreme Court of Appeal's further finding that the reporting order breached the

131 Hlophe (n 130) para 11.

132 Hlophe para 13.

133 Hlophe (n 130).

134 Hlophe para 15.

135 Hlophe para 21.

136 Hlophe para 27. An interim order to meaningfully engage with the applicants was issued in Hlophe (n 130).

137 For a summary of this protracted litigation, see SERI 'Hlophe and Others $v$ City of Johannesburg and Others ("Hlophe")' (2013) SERI-SA http://www.seri-sa.org/ index.php/19-litigation/case-entries/196-hlophe-and-others-v-city-ofjohannesburg-and-others-hlophe (accessed 15 September 2014).

138 Respondent's heads of argument in City of Johannesburg v Hlophe SCA Case 1035/ 2014.

139 City of Johannesburg Metropolitan Municipality v Hlophe 20152 All SA 251 (SCA) para 26.

140 City of Johannesburg para 27. 
separation of powers in that it purported 'to give directions to the City in respect of what is required to comply with its constitutional obligations to provide temporary accommodation to homeless persons in general' cannot be supported. ${ }^{141}$

\subsection{Supervision}

The effectiveness of a remedy can be assessed by determining to what extent it can realise the capabilities underlying the infringed socioeconomic right. Capability realisation, therefore, is the measure against which the effectiveness of a remedy can be judged. In Fose $e^{142}$ the Constitutional Court echoed the need for effective remedies: ${ }^{143}$

In our context an appropriate remedy must mean an effective remedy, for without effective remedies for breach, the values underlying and the rights entrenched in the Constitution cannot properly be upheld or enhanced ... The courts have a particular responsibility in this regard and are obliged to 'forge new tools' and shape innovative remedies, if needs be, to achieve this goal.

By adopting a capabilities approach to remedies, courts are able to discharge their responsibility by shaping innovative, effective remedies. However, participatory processes aimed at informational broadening and explicit reasoning are not sufficient. In addition, the retention of supervision is a crucial element of an effective remedy. ${ }^{144}$

Supervisory jurisdiction is not only justified where the state has demonstrated intransigence, but also where basic socio-economic capabilities are imperilled by unreasonable resource allocation decisions. Without an effective remedy, 'irremediable' damage can result to those whose capabilities are being deprived as a result of the right-infringement. ${ }^{145}$ By monitoring the various participatory processes aimed at informational broadening, courts can ensure that relevant capabilities and concomitant allocative needs are properly identified in a situation of bargaining parity. ${ }^{146}$ Furthermore, the continued involvement of the court allows it to adapt its orders based on the information that comes to light during the process of engagement. Supervision is also necessary to ensure that revised resource allocation decisions are not only aimed at capability realisation for the parties to the litigation, but also to others similarly situated. ${ }^{147}$

Courts can accordingly discharge their constitutional duty to devise effective remedies by compelling the state to report back to the court

141 City of Johannesburg para 28.

142 Fose (n 88).

143 Fose (n 88) para 69 (my emphasis).

144 Rodríguez-Garavito ( $\mathrm{n}$ 62) 1691-1692. The retention of supervision is made possible by the broad provision made for remedies in sec 172 of the Constitution and by sec 8 of PAJA.

145 Roach \& Budlender ( $\mathrm{n}$ 45) 334.

146 Liebenberg (n 107).

147 As above. 
regarding the steps it has taken to formulate reasonable allocative decisions in consultation with a broad range of stakeholders. Such plans must be made subject to judicial approval, and should facilitate further public scrutiny. In Allpay $\|^{148}$ a reporting back order, and not a structural interdict, was granted. State reports thus were not subjected to judicial approval. The subsequent discharge of judicial supervision, based on false reassurances provided by the Department of Social Development, almost led to a catastrophe in social grant administration, ${ }^{149}$ thereby highlighting the crucial importance of retained judicial supervision where systemic socio-economic rights infringements are at issue. In appropriate cases, a court may revise its order and adapt its initial explicit normative guidelines in light of the information garnered during the process of engagement. Where participatory processes have not been sufficiently adhered to, a court can issue explicit instructions compelling the state to rectify defects in relation to its engagement efforts. In so doing, the state can remedy any lacunae in its allocative plan that resulted from the participation deficit in the engagement process.

Where the state files a report regarding its progress in formulating and implementing reasonable resource allocation decisions, other stakeholders should be granted the first opportunity to comment on such a report. This may to some extent alleviate the supervising court's burden. The assistance of organisations or ad hoc commissions ${ }^{150}$ may also be solicited in order to supervise the implementation of the order, with the court only approving plans or issuing further directions at protracted intervals. ${ }^{151}$ The retention of supervision can thus catalyse a truly collaborative partnership between the courts, the state, and all stakeholders that have an interest in reasonable resource allocation decisions aimed at socio-economic capability realisation.

\section{Conclusion}

A capabilities approach to remedies postulates relief that may effectively vindicate the capabilities underlying a socio-economic right that was infringed upon through disproportionate resource allocation. The effectiveness of a remedy thus can be assessed against the

148 Allpay II (n 1).

149 Black Sash I (n 1).

150 For the use of commissions in India to monitor the implementation of remedies, see Bhagwati (n 84) 575-577; Cassels (n 84) 500506.

151 A supervising court must explicitly define roles and functions to avoid the confusion that resulted when the South African Human Rights Commission agreed to 'monitor' state compliance with its constitutional obligations in the wake of the judgment in Grootboom (n 28). See Pillay (n 29) 14. See further M Ebadolahi 'Using structural interdicts and the South African Human Rights Commission to achieve the judicial enforcement of economic and social rights in South Africa' (2008) 83 New York University Law Review 1565 1602-1605. 
measure of capability realisation. Furthermore, in this article it was argued that a capabilities approach to remedies requires the incorporation of three features that interact with each other in the common pursuit of ensuring effectiveness. These are participation aimed at broadening the information available to the court and the state for the formulation of an effective remedy; explicitness in the provision of normative guidelines by the court and the formulation of a remedial plan by the state; and the retention of supervision by the court. It was further shown that the structural interdict can be designed so as to include all three these crucial capabilities-based features.

Moreover, a capabilities approach to the design of a structural interdict is capable of substantially addressing concerns that courts are constitutionally and institutionally incompetent fora for the adjudication of polycentric resource allocation decisions. The capabilities precept to broaden the information available to the state to the greatest extent possible in revising its allocative decisions grants the state sufficient latitude to devise its own allocative plans within its spheres of competence. A court thus provides normative parameters in which such remediation must occur, but leaves the details of allocative decisions to the branches of government best equipped to grapple with matters of resource allocation. Furthermore, the flexibility inherent in a participatory remedy coupled with on-going judicial supervision enables polycentric consequences to be dealt with sequentially, as they arise. Polycentric effects are also minimised in proportion to the range of interests identified and represented through a process of informational broadening.

A capabilities approach to remedies thus aims at institutionalising capabilities-focused resource allocation decisions for the benefit of all those whose socio-economic rights remain unfulfilled. 